\title{
Effect of the acrylic occlusal device on the stress distribution in the external hexagon implant in situations of dental tightening. A 3D finite element analysis
}

Efeito do dispositivo oclusal acrílico na distribuição de tensões no implante de hexágono externo em situações de aperto dentário. Uma análise de elementos finitos 3D

Efecto del dispositivo oclusal acrílico sobre la distribución de tensiones sin implante hexagonal externo en situaciones de estanqueidad dental. Un análisis de elementos finitos en 3D

Victor Eduardo de Souza Batista ORCID: https://orcid.org/0000-0003-0246-8101 University of Western São Paulo, Brazil E-mail: victor_edsb@hotmail.com Lorena Scaioni Silva

ORCID: https://orcid.org/0000-0002-5370-8323 University of Western São Paulo, Brazil E-mail: lorenascaioni@gmail.com Anderson Catelan

ORCID: https://orcid.org/0000-0002-5916-8655 University of Western São Paulo, Brazil E-mail: ander.catelan@gmail.com

Carolina Santinoni dos Santos

ORCID: https://orcid.org/0000-0001-5153-2419 University of Western São Paulo, Brazil E-mail: carolsantinoni@msn.com Aljomar José Vechiato-Filho ORCID: https://orcid.org/0000-0002-0442-0294 University of Western São Paulo, Brazil E-mail: aljomarvechiatoflo@gmail.com

Ronaldo Silva Cruz

ORCID: https://orcid.org/0000-0003-3214-2479 University of Western São Paulo, Brazil E-mail: ronald.mb@hotmail.com

Christine Men Martins ORCID: https://orcid.org/0000-0002-5429-509X University of Western São Paulo, Brazil E-mail: christinemen@ hotmail.com

Cleidiel Aparecido Araújo Lemos ORCID: https://orcid.org/0000-0001-8273-489X Federal University of Juiz de Fora, Brazil E-mail: cleidiel@gmail.com Fellippo Ramos Verri ORCID: https://orcid.org/0000-0001-5688-1669 University of Western São Paulo, Brazil E-mail: fellippo@gmail.com

\begin{abstract}
The aim in the present study was to analyze the stress in the external hexagon implant (EH) in a situation of parafunction on three-unit implant-supported prostheses with and without the use of the acrylic occlusal device (AOD) using three-dimensional (3D) finite element analysis (FEA). Eight 3D models referring to the posterior maxilla with three EH supporting single and or splinted screwed metal-ceramic restoration and use of the AOD. AOD was modeled with a thickness of $2 \mathrm{~mm}$. EHs were analyzed using von Mises criteria in the ANSYS 19.2 program. AOD showed to be effective in reducing stress in the EH. However, the use of the AOD was not effective enough to suggest the non-splinting of EH dental implant. The association of splinting and the use of an AOD in the posterior region of the maxilla may be an effective way to decrease the stress in the EH implant in a situation of parafunction.

Keywords: Finite element analysis; Dental implants; Biomechanical phenomena.
\end{abstract}




\section{Resumo}

O objetivo no presente estudo foi analisar a tensão no implante de hexágono externo (HE) em situação de parafunção em próteses de três elementos implantossuportadas com e sem o uso do dispositivo oclusal de acrílico (DOA) por meio da análise de elementos finitos (AEF) tridimensional (3D). Oito modelos 3D simulados referentes à região posterior da maxila com três HE suportando próteses metalocerâmica unitária e/ou esplintada parafusada e uso de DOA. O DOA foi modelado com espessura de $2 \mathrm{~mm}$. Os HEs foram analisados usando os critérios de von Mises no programa ANSYS 19.2. O DOA mostrou-se eficaz na redução da tensão no HE. No entanto, o uso do DOA não foi eficaz o suficiente para sugerir a não esplintagem do implante dentário HE. A associação de esplintagem e o uso de DOA na região posterior da maxila pode ser uma forma eficaz de diminuir a tensão no implante de HE em situação de parafunção.
\end{abstract}

Palavras-chave: Análise de elementos finitos; Implantes dentários; Fenômenos biomecânicos.

\title{
Resumen
}

El objetivo em el presente estudio fue analizar la tensión en el implante de hexágono externo (HE) en una situación de parafunción en prótesis implantosoportadas de tres unidades con y sin el uso del dispositivo oclusal acrílico (DOA) utilizando tres dimensiones (3D) análisis de elementos finitos. Ocho modelos 3D referidos al maxilar posterior con tres HE que soportan la restauración metalocerámica atornillada y/o ferulizada y el uso del AOD. El DOA se modeló con un espesor de $2 \mathrm{~mm}$. Los HE se analizaron utilizando los criterios de von Mises en el programa ANSYS 19.2. DOA demostró ser eficaz para reducir el estrés en el HE. Sin embargo, el uso del DOA no fue lo suficientemente eficaz como para sugerir la no ferulización del implante dental HE. La asociación de ferulización y el uso de un DOA en la región posterior del maxilar puede ser una forma eficaz de disminuir la tensión en el implante HE en una situación de parafunción.

Palabras clave: Análisis de elementos finitos; Implantes dentales; Fenómenos biomecánicos.

\section{Introduction}

The advent of dental implants has enabled the rehabilitation of patients with partial edentulism in a more functional way, showing satisfactory results in terms of function and aesthetics and offering predictable rehabilitation with high long-term success rate (Albrektsson et al., 2012; Jung et al., 2008; Branemark at al., 1997). However, an inadequate planning of implantsupported rehabilitation may interfere in the treatment outcome, generating mechanical and biological complications that lead to dental implant failure (Abu-Hammad et al., 2007; de Souza Batista et al., 2019).

In order to avoid mechanical complications (e.g., dental implant fracture), an important factor to assist in the planning and success of implant-supported rehabilitation is the knowledge about the stress distribution throughout the dental implant, since the occlusal load is transferred to the dental implant and then to the adjacent bone tissue, which makes biomechanics a crucial factor for the success of the treatment (Rubo et al., 2010). Several factors may affect the stress distribution in the oral rehabilitation, such as: geometric of the platform, number of dental implants in rehabilitation, length and diameter of the dental implants, splinting of the crowns, type of occlusal load (functional or parafunctional), structure of the implant surface, bone loss level around the dental implant, the properties of the material used to confection the dental implant and the design of the threads (Geng et al., 2001; Torcato et al., 2014; de Souza Batista et al., 2017a; de Souza Batista et al., 2020; Lemos et al., 2021). Thus, to study the effect of occlusal load on fixed dental prosthesis as well as the way to decrease the stress in the dental implant is important to avoid implant failure.

The geometric of the platform is extremely important in the distribution of occlusal forces throughout the dental implant, being divided into internal connection, represented by morse taper (MT) and internal hexagon (IH), and external connection, represented by external hexagon (EH) (Lemos et al., 2018a). EH implant has been used for decades and still is used in the clinical routine of professional who act in the implantology area due to show simplicity and predictability (Kourtis et al., 2017; Maeda et al., 2006). Camps-Font e et al. showed that the strength of the dental implant is derived from the thickness of the dental implant wall and that the EH have a greater width of the walls when compared to MT and IH, thus being a connection with less occurrence of fractures compared to other connections (Camps-front et al., 2020). Nevertheless, fractures of the EH dental implant are reported in the literature (Balshi et al., 1996; Weinberg et al., 1993; Eckert et al., 2000). 
The splitting of the dental implant is another important factor that may collaborate with a favorable stress distribution in the rehabilitation (Bergkvist et al., 2008; Pellizzer et al., 2014; Lemos et al., 2018b). However, splinting or not splinting is a doubt that arises with frequency among clinicians, since the splinting may improve the stress distribution compared to single crowns (Bergkvist et al., 2008; Pellizzer et al., 2014; Pellizzer et al., 2015; Lemos et al., 2018b), mainly in low quality bone or in situation of occlusal overload (Wang et al., 2002; de Souza Batista et al., 2019). In contrast, single crowns (not splinted) may offer better hygiene due to interproximal access, greater passivity in the insertion of the prosthesis and greater ease in making an adequate emergence profile (Solnit, Schneider et al., 1998; Vázquez Álvarez et al., 2015).

In patients who have parafunction, prosthetic rehabilitation with dental implant is a clinical challenge, since excessive occlusal forces may generate mechanical complications, leading to failure of rehabilitation (Manfredini et al., 2014). Proper planning and monitoring are primordial, and the use of an acrylic occlusal device (AOD) could be suggested to avoid inducing stress at the implant-bone interface (dos Santos Marsico et al., 2017; Radaelli et al., 2018). This hypothesis was based on the assumption that interposing a rigid occlusal apparatus would be able to reduce loading forces on the long axis of the implant during the parafunction (Suganuma et al., 2013). Although the literature has presented some finite element studies that evaluated the effect of the AOD on implant-supported rehabilitation (dos Santos Marsico et al., 2017; Radaelli et al., 2018; Silva et al., 2021), this is the first FEA that ascertains the influence of the AOD in the stress distribution on EH dental implants placed in the posterior maxilla region.

Three-dimensional (3D) finite element analysis (FEA) has been widely used in the implantology area to assess biomechanics in a static way (Verri et al., 2014; Torcato et al., 2015; Verri et al., 2017; de Souza Batista et al., 2017a; Lemos et al., 2018c, Fabris et al., 2021). The analysis is defined as a numerical computational simulation that determines the biomechanical behavior through models of complex geometric structures and it may predict a greater potential for failure after load application in a given structure, and consequently, collaborate to achievement an appropriate planning for each clinical situation, increasing the chances of success (Verri et al., 2014; Chu CM et al., 2012).

The objective in the present study was to analyze the stress in the EH dental implant in a situation of parafunction on three-unit implant-supported prostheses with and without the use of the AOD using the 3D-FEA. The study hypothesis was that the AOD could reduce the stress in the EH dental implant in both single and splinted crowns.

\section{Methodology}

\subsection{Experimental design}

The finite element method used was based on previously published studies (de Souza Batista et al., 2017b; Lemos et al., 2018b). A clinical question in cases of tooth tightening motivated the present study: May the use of AOD reduce stress in the EH implant to the point of suggesting non-splinting of implants?

To answer this question, the present study was developed considering single and splinted crowns, use of AOD, functional and parafunctional loading (Table 1).

\subsection{Three-dimensional modeling}

Eight 3D models were simulated (Table 1) representing a maxillary bone block referring to the region from $1^{\circ}$ premolar (PM) to $1^{\circ}$ right molar $(\mathrm{M})$, with three $\mathrm{EH}$ implants of $4.0 \mathrm{~mm}$ in diameter and $7.0 \mathrm{~mm}$ in length (Conexão Sistemas de Prótese Ltda., Arujá, São Paulo, Brazil), supporting a prosthesis of three screwed metal-ceramic elements (Figure 1).

Bone tissue design was performed by trabecular bone simulation in the central region surrounded by $1 \mathrm{~mm}$ of cortical bone, simulating type IV bone (Lekholm, Zarb et al., 1985). In the InVesalius program (CTI, Campinas, São Paulo, Brazil), bone tissue was obtained by digitizing a computed tomography and the simplification of the surfaces was performed in the 
Rhinoceros 4.0 program (NURBS Modeling for Windows, Seattle, Washington, EUA).

Table 1. Description of models.

\begin{tabular}{ccccc}
\hline Model & Type of prosthesis & Acrylic Occlusal device & Loading & Nodes/Elements \\
\hline M1 & & With & Functional & $327.694 / 1.671 .436$ \\
M2 & \multirow{2}{*}{ Single crowns } & Without & & $223.767 / 1.119 .641$ \\
M3 & & With & Parafunctional & $327.694 / 1.671 .436$ \\
M4 & & Without & & $223.767 / 1.119 .641$ \\
M5 & & With & \multirow{2}{*}{ Functional } & $424.513 / 2.187 .799$ \\
M6 & \multirow{2}{*}{ Splinted crowns } & Without & & $230.079 / 1.153 .414$ \\
M7 & & With & \multirow{2}{*}{ Parafunctional } & $424.513 / 2.187 .799$ \\
M8 & & Without & & $230.079 / 1.153 .414$ \\
\hline
\end{tabular}

Source: Authors.

Figure 1. Three-dimensional finite element models with all simulated structures. Red points represent the application points of the occlusal forces.

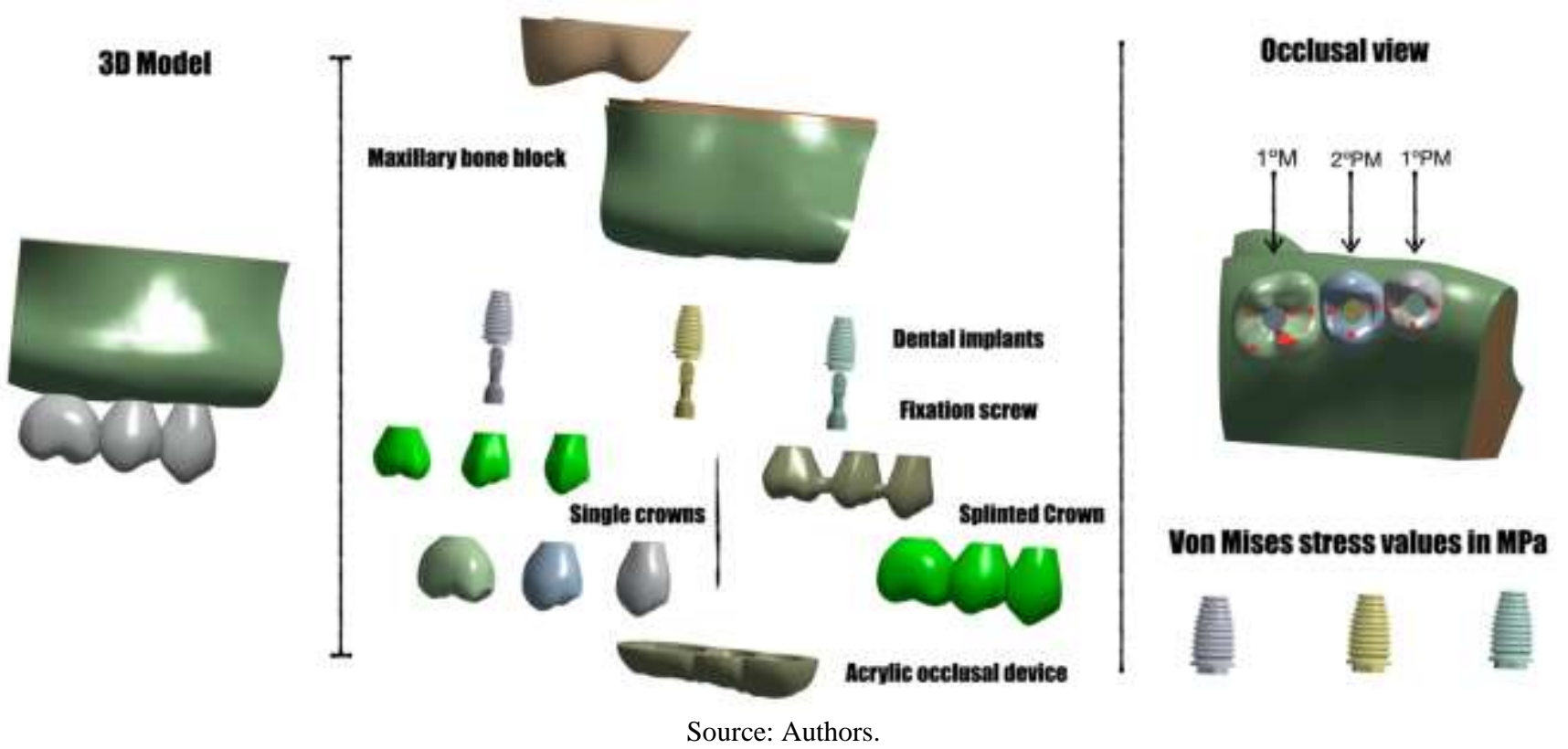

The design of the EH implant was obtained by simplifying an original implant design with $4.0 \mathrm{~mm}$ in diameter and $7.0 \mathrm{~mm}$ in length (Verri et al., 2016). In addition, UCLA abutment (Universal Castable Long Abutment) was simulated, but with a rotational system for splinted prostheses and an anti-rotation system for single prostheses. The dimension of the occlusal table of the crown was the same for all simulated models.

Dental implants, abutments, metal ceramic crowns and screws were simplified using the SolidWorks 2016 (SolidWorks Corpo, Waltham, Massachusetts, USA) and Rhinoceros 4.0 programs, and were all the same for the eight models. AOD was modeled with $2 \mathrm{~mm}$ thick, the flat occlusal surface, and the buccal and lingual extensions involving the occlusal third of the teeth. In addition, the AOD was simulated with $100 \%$ contact with the dental surfaces. Finally, all geometries were exported for discretization in the finite element ANSYS 19.2 program. 


\subsection{Configuration of the 3D analysis, contact conditions, contouring, and loading}

For the analysis of finite elements, the phases of pre-processing, resolution (mathematical calculations) and postprocessing (visualization of results) were performed in ANSYS 19.2. Thus, the entire modeled set described previously was imported in a specific program for the elaboration of ANSYS 19.2 finite element models (Southpointe, PA, USA) to incorporate the mechanical properties of the components involved in the study, as well as the elaboration of the meshes of the structures, which was defined as parabolic tetrahedral solid elements.

In addition, the mechanical properties of each simulated material were attributed to the meshes using the values in the literature (Sevimay et al., 2005; Santiago Junior et al., 2013; de Souza Batista et al., 2017a; Lemos et al., 2018b; Verri et al., 2017; dos Santos Marsico et al., 2017) (Table 2). All materials involved in the study were considered homogenous, isotropic and linear. The FEA was of the static linear type, by constant load application.

Table 2. Material properties.

\begin{tabular}{cccc}
\hline Structures & $\begin{array}{c}\text { Elastic modulus } \\
(\mathbf{E})(\mathbf{G P a})\end{array}$ & $\begin{array}{c}\text { Poisson ratio } \\
(\mathbf{v})\end{array}$ & References \\
\hline $\begin{array}{c}\text { Trabecular bone with low density } \\
\text { (type bone IV) }\end{array}$ & 1,10 & 0,30 & Sevimay et al., 2005 \\
Cortical bone & 13,7 & 0,30 & de Souza Batista et al., \\
Titanium & 110,0 & 0,35 & 2017a \\
Ni-Cr alloy & 206,0 & 0,33 & Vemos et al., 2018b \\
Feldspathic porcelain & 82,8 & 0,35 & $\begin{array}{c}\text { Santiago Junior et al., 2013 } \\
\text { dos Santos Marsico et al., } \\
\text { Acrylic resin }\end{array}$ \\
\end{tabular}

GPa, gigapascal; Ni-Cr, nickel-chromium alloy. Source: Authors.

Contact conditions was defined being only the contact interface between the prosthetic component/dental implant and crowns/AOD as juxtaposed and the other contact interfaces as bonded. The boundary conditions were established as fixed on all axes (x, y e z). After the application of loads, the entire crown structure, abutments, dental implant and all bone tissue surrounding the implants could move and be intruded, leaving only the base of the bone block fixed and without movement (de Souza Batista et al., 2017a). The applied force was 300N in axial direction for functional loading, being divided into 11 points of application on the occlusal surface of premolars and molars (Figure 2) (Meena et al., 2014). For parafunctional loading, the applied force was $800 \mathrm{~N}$ in an axial direction at 11 points (Nishigawa et al., 2001). For models with an AOD, the loading points were the same as previously described and this positioning was transferred by reference lines previously performed in Rhinoceros 4.0.

\subsection{Analysis of results}

The mathematical problem was generated and solved, and the results were visualized using the ANSYS 19.2 solver. Stress in dental implants was obtained through the von Mises map. The von Mises analysis was used to evaluate the EH dental implants to understand the biomechanical behavior of ductile materials. The von Mises values was reported in megapascal (MPa). 


\section{Results}

Among the three EH dental implants analyzed $\left(1^{\circ} \mathrm{PM}, 2^{\circ} \mathrm{PM}\right.$ and $\left.1^{\circ} \mathrm{M}\right)$, the dental implant positioned in the $1^{\circ} \mathrm{M}$ area showed the highest von Mises stress value for all models. Parafunctional loading increased the stress in the EH dental implants when compared to the functional loading for both single crowns (M1-M4) and for splinted crowns (M5-M8) (Figure 2). In face of parafunctional loading, the association of crown splinting with the AOD (M7) generated the lowest values of stress in the EH dental implants. In addition, the use of the AOD decreased the stress in the EH implant in planning considering single crowns (M4 compared to M3), mainly for $1^{\circ} \mathrm{M}$. In models without the OAD under parafunctional loading (M4 and M8), crown splinting (M8) reduced the stress in the EH implants when compared to single crowns (M4), mainly in the $1^{\circ} \mathrm{M}$. In addition, the model with single crowns under parafunctional loading (M4) showed the highest stress values in the EH implants, especially in the $1^{\circ} \mathrm{M}$.

Figure 2. Values of von Mises stress in dental implant. M, model; AOD, acrylic occlusal device.

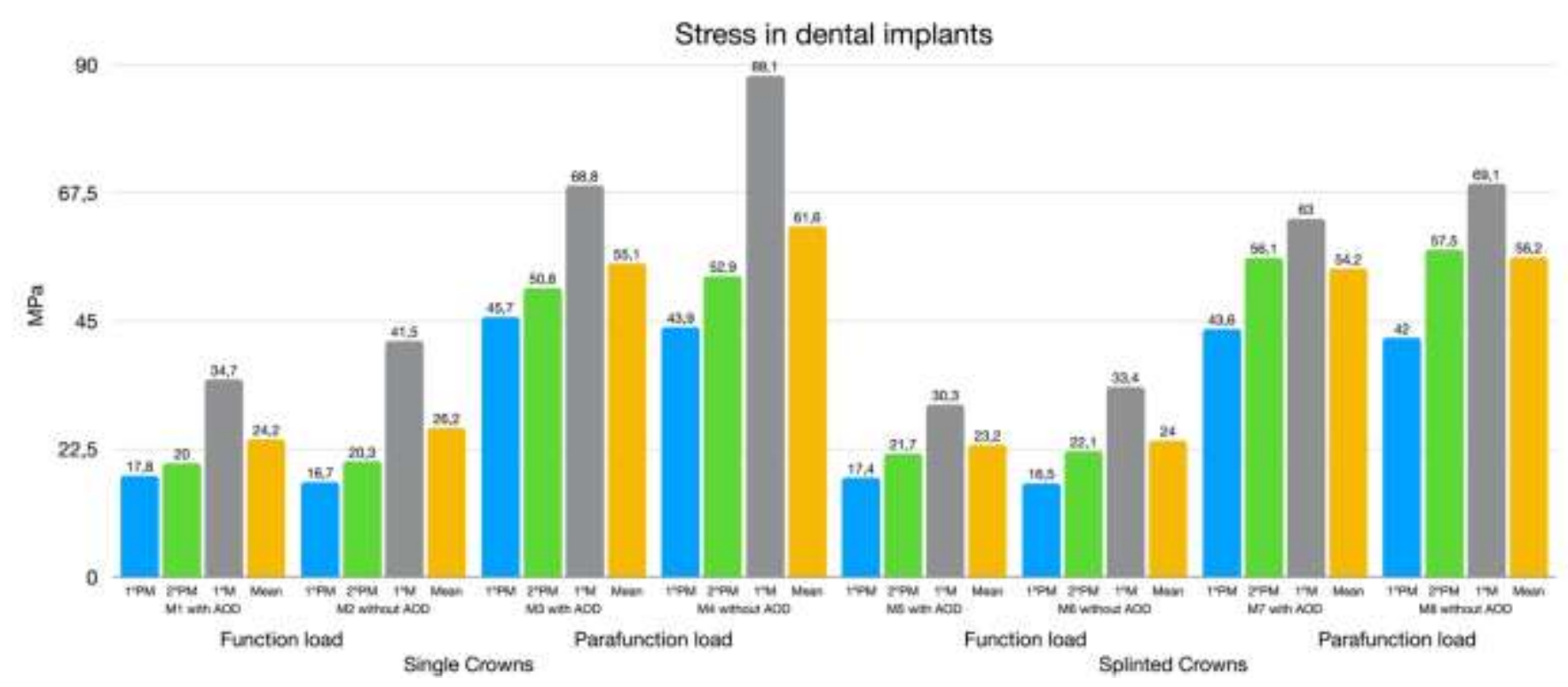

Source: Authors.

\section{Discussion}

FEA in the present study allowed to verify that the AOD provided an improvement in the biomechanical behavior by reducing the stress in the EH dental implant. Therefore, the study hypothesis was accepted. However, the use of the AOD was not effective enough to the point of suggesting non-splinting of the EH implants (answering the initial question that motivated the present work "May the use of AOD the stress in the EH implant to the point of suggesting its non-splinting?").

Parafunctional loading resulted an increase in stress in EH dental implants when compared to functional loading in both single and splinted crowns. Data that corroborate with studies already published in the literature (Torcato et al., 2014; Torcato et al., 2015; Radaelli et al., 2018). The reason of the highest stress was located in the $1^{\circ}$ molar may be justified due to the presence of a larger area and two centric holding cusps, resulting in a greater application of forces (Lemos et al., 2018b).

Despite of high success rates, the existence of parafunctional habits was listed as a factor of risk for treatment with dental implants (Manfredini \& Lobbezoo 2014), due to the increase of fractures of screws and even of the dental implant, where the grinding and tightening have been considered the most common reasons of increase of stress in the dental implant (Naert et al., 1992; Balshi et al., 1996; Gealh et al., 2010; Misch, 2002), in agreement with the results of the present study. The 
geometric of the platform is strictly associated with the pattern of stress distribution, as verified in the previous study (Ali Balik et al., 2012; Yamanishi et al., 2012; Torcato et al., 2015) and the EH presents a greater resistance to fatigue and fracture when compared to other dental implant types (Font et al., 2020; Ribeiro et al., 2011). As shown a study by Camps-Font et al. (2020), EH presents thicker walls, consequently, it is more resistant; however, for dental implants with internal connection (MT and IH), this increase of the stress in the dental implant may be a critical factor (Camps-Font et al., 2020). Despite the evidence regarding the resistance of the EH implant, the literature reports implant fractures with this type of connection (Balshi, 1996; Weinberg, 1993; Eckert et al., 2000). As a suggestion for future studies, studying the biomechanical effect of the AOD in situations of parafunction in an internal connection implant using MEF-3D may be interesting in order to predict fracture situations.

Several authors have stated that the splinting is effective in reducing stress in the dental implant when compared with single crowns (Pellizzer et al., 2014; Pellizzer et al., 2015; Lemos et al., 2018b; Lemos et al., 2018c; de Souza Batista et al., 2019; Bergkvist et al., 2008; Hauchard et al., 2011), in accordance with the result provided in the present study. This fact may be explained due to splinting provides a better stress distribution when compared to a single implant-supported prosthesis (Pellizzer et al., 2014), since the rigid bonding formed between the crowns provides the load sharing between the dental implants and contributes to decrease the stress generated in the components forward occlusal loads (Lemos et al., 2018b; Lemos et al., 2018c).

A significant reduction in the stress values of dental implants was observed when the splinting was associated with the use of an AOD in a parafunction situation. This finding may be understood following the same theory of splinting, since the AOD may assist in the sharing of stress generated by the parafunctional load between the crowns (Dos Santos Marsico et al., 2017; Radaelli et al., 2018). Hypothetically, the effect of load sharing in the splinted model using an AOD was doubled. Extrapolating the results to clinical routine, it would be plausible to suggest the making of splinted crowns followed by the installation of a AOD at the end of the rehabilitation in the plan of treatment of a partial edentulous with extensive free extremity associated with parafunction in order to reduce the stress in the EH dental implant.

FEA is considered an excellent method for prosthetic planning (Pesqueira et al., 2014). However, the simulation of materials with characteristics as isotropic, homogeneous and linearly elastic, as well as previously published studies (Torcato et al., 2015; de Souza Batista et al., 2017a; Radaelli et al., 2018), may be considered as study limitation, since living tissues and materials are more dynamic (Iplikcioğlu, Akca et al., 2002). This factor suggests the execution of randomized clinical trials studies in order to offer more accurate data.

Although some studies have evaluated the effect of the AOD on implant-supported rehabilitation using FEA (dos Santos Marsico et al., 2017; Radaelli et al., 2018), it is noteworthy that this is the first finite element analysis that investigates the influence of the AOD is the stress distribution of the EH dental implant placed in the posterior of the maxilla. The literature is scarce of studies that have evaluated the influence of the use of AOD in dental implants, suggesting the development of biomechanical analyzes to guide the prosthetic rehabilitation upon parafunctional loads.

\section{Conclusion}

Within the limitations of the study, it was possible to conclude that the parafunctional loading increased the stress in the EH implants when compared to the functional loading. The use of the AOD reduced the stress in the EH implant and the use of splinted crowns in the posterior region of the maxilla associated with the use of an AOD is an effective way to decrease the stress in the EH dental implant in a situation of parafunction. Further studies about the effect of AOD in internal connections (morse tapper and internal hexagon) are necessary to provide new information to the clinician. 


\section{Acknowledgments}

This research was supported by Scholarship of Research Foundation of the State of São Paulo - FAPESP \# 2019/18178-7.

\section{References}

Abu-Hammad, O., Khraisat, A., Dar-Odeh, N., Jagger, D. C., \& Hammerle, C. H. (2007). The staggered installation of dental implants and its effect on bone stresses. Clinical Implant Dentistry and Related Research, 9 (3), 121-127.

Albrektsson, T., Donos, N., \& Working Group 1. (2012). Implant survival and complications. The Third EAO consensus conference 2012. Clinical Oral Implants Research, 23 (Suppl 6), 63-65.

Balik, A., Karatas, M. O., \& Keskin, H. (2012). Effects of different abutment connection designs on the stress distribution around five different implants: a 3 dimensional finite element analysis. Journal of Oral Implantology, 38, 491-496.

Balshi, T. J. (1996). An analysis and management of fractured implants: a clinical report. International Journal of Oral and Maxillofacial Implants, 11 (5), 660-666.

Bergkvist, G., Simonsson, K., Rydberg, K., Johansson, F., \& Dérand, T. (2008). A finite element analysis of stress distribution in bone tissue surrounding uncoupled or splinted dental implants. Clinical Implant Dentistry and Related Research, 10 (1), 40-46.

Brånemark, P. I., Hansson, B. O., Adell, R., Breine, U., Lindström, J., Hallén, O., \& Ohman, A. (1977). Osseointegrated implants in the treatment of the edentulous jaw. Experience from a 10-year period. Scandinavian Journal of Plastic and Reconstructive Surgery. Supplementum, 16, 1-132.

Camps-Font, O., González-Barnadas, A., Mir-Mari, J., Figueiredo, R., Gay-Escoda, C., \& Valmaseda-Castellón, E. (2020). Fracture resistance after implantoplasty in three implant-abutment connection designs. Medicina Oral, Patología Oral y Cirugía Bucal, 25 (5), e691.

Chu, C. M., Huang, H. L., Hsu, J. T., \& Fuh, L. J. (2012). Influences of internal tapered abutment designs on bone stresses around a dental implant: Three-dimensional finite element method with statistical evaluation. Journal of Periodontology, 83 (1), 111-118.

de Souza Batista, V. E., Verri, F. R., Almeida, D. A. D. F., Santiago Junior, J. F., Lemos, C. A. A., \& Pellizzer, E. P. (2017a). Finite element analysis of implant-supported prosthesis with pontic and cantilever in the posterior maxilla. Computer Methods in Biomechanics and Biomedical Engineering, 20 (6), 663-670.

de Souza Batista, V. E., Verri, F. R., Almeida, D., Santiago Junior, J. F., Lemos, C., \& Pellizzer, E. P. (2017b). Evaluation of the effect of an offset implant configuration in the posterior maxilla with external hexagon implant platform: A 3-dimensional finite element analysis. The Journal of Prosthetic Dentistry, $118(3), 363-371$

de Souza Batista, V. E., Verri, F. R., Lemos, C. A., Cruz, R. S., Noritomi, P. Y., \& Pellizzer, E. P. (2020). A 3D Finite Element Analysis of Bone Tissue in $3-$ Unit Implant-Supported Prostheses: Effect of Splinting Factor and Implant Length and Diameter. The European Journal of Prosthodontics and Restorative Dentistry. 10.1922/EJPRD_2098deSouzaBatista08. Online ahead of print.

de Souza Batista, V. E., Verri, F. R., Lemos, C., Cruz, R. S., Oliveira, H., Gomes, J., \& Pellizzer, E. P. (2019). Should the restoration of adjacent implants be splinted or nonsplinted? A systematic review and meta-analysis. The Journal of Prosthetic Dentistry, 121 (1), 41-51.

Eckert, S. E., Meraw, S. J., Cal, E., \& Ow, R. K. (2000). Analysis of incidence and associated factors with fractured implants: a retrospective study. International Journal of Oral \& Maxillofacial Implants, 15 (5), 662-667.

Fabris, R. R., Caldas, R. A., Miranda, M. E., Borba, P., Oliveri, K. A. N., Brandt, W. B., Vitti, R. P. (2021). Comparative stress evaluation of different types of prosthetic abutment and crown with an internal connection implant. Research, Society and Development, 10 (4), e7010413933.

Gealh, W. C., Mazzo, V., Barbi, F., \& Camarini, E. T. (2011). Osseointegrated implant fracture: causes and treatment. Journal of Oral Implantology, 37 (4), 499-503.

Geng, J. P., Tan, K. B., \& Liu, G. R. (2001). Application of finite element analysis in implant dentistry: a review of the literature. The Journal of Prosthetic Dentistry, 85 (6), 585-598.

Hauchard, E., Fournier, B. P., Jacq, R., Bouton, A., Pierrisnard, L., \& Naveau, A. (2011). Splinting effect on posterior implants under various loading modes: a 3D finite element analysis. The European Journal of Prosthodontics and Restorative Dentistry, 19 (3), 117-122.

İplikçioğlu, H., \& Akça, K. (2002). Comparative evaluation of the effect of diameter, length and number of implants supporting three-unit fixed partial prostheses on stress distribution in the bone. Journal of Dentistry, 30 (1), 41-46.

Jung, R. E., Pjetursson, B. E., Glauser, R., Zembic, A., Zwahlen, M., \& Lang, N. P. (2008). A systematic review of the 5-year survival and complication rates of implant-supported single crowns. Clinical Oral Implants Research, 19 (2), 119-130.

Kourtis, S., Damanaki, M., Kaitatzidou, S., Kaitatzidou, A., \& Roussou, V. (2017). Loosening of the fixing screw in single implant crowns: predisposing factors, prevention and treatment options. Journal of Esthetic and Restorative Dentistry, 29 (4), 233-246.

Lekholm U, Zarb G. 1985. Patient selection and preparation. In: Branemark PI, Zarb G, Albrektsson T, editors. Tissue integrated prostheses: osseointegration in clinical dentistry. Chicago (IL): Quintessence Publishing 1985;199-211. 
Lemos, C. A. A., Verri, F. R., Bonfante, E. A., Júnior, J. F. S., \& Pellizzer, E. P. (2018a). Comparison of external and internal implant-abutment connections for implant supported prostheses. A systematic review and meta-analysis. Journal of Dentistry, 70, 14-22.

Lemos, C. A. A., Verri, F. R., Noritomi, P. Y., Kemmoku, D. T., de Souza Batista, V. E., Cruz, R. S., \& Pellizzer, E. P. (2021). Effect of bone quality and bone loss level around internal and external connection implants: A finite element analysis study. The Journal of Prosthetic Dentistry, 125 (1), 137.e1137.e10.

Lemos, C. A. A., Verri, F. R., Santiago Júnior, J. F., Almeida, D. A. D. F., Batista, V. E. D. S., \& Noritomi, P. Y. (2018b). Retention system and splinting on morse taper implants in the posterior maxilla by 3D finite element analysis. Brazilian Dental Journal, 29c(1), 30-35.

Lemos, C. A. A., Verri, F. R., Santiago Junior, J. F., de Souza Batista, V. E., Kemmoku, D. T., Noritomi, P. Y., \& Pellizzer, E. P. (2018c). Splinted and nonsplinted crowns with different implant lengths in the posterior maxilla by three-dimensional finite element analysis. Journal of Healthcare Engineering, 2018,3163096 .

Maeda, Y., Satoh, T., \& Sogo, M. (2006). In vitro differences of stress concentrations for internal and external hex implant-abutment connections: a short communication. Journal of Oral Rehabilitation, 33 (1), 75-78.

Manfredini, D., Poggio, C. E., \& Lobbezoo, F. (2014). Is bruxism a risk factor for dental implants? A systematic review of the literature. Clinical Implant Dentistry and Related Research, 16 (3), 460-469.

Marsico, V. D. S., Lehmann, R. B., de Assis Claro, C. A., Amaral, M., Vitti, R. P., Neves, A. C. C., \& da Silva Concilio, L. R. (2017). Three-dimensional finite element analysis of occlusal splint and implant connection on stress distribution in implant-supported fixed dental prosthesis and peri-implantal bone. Materials Science \& Engineering. C, Materials for Biological Applications, 80, 141-148.

Meena, A., Jain, V., Singh, N., Arora, N., \& Jha, R. (2014). Effect of implant-supported prosthesis on the bite force and masticatory efficiency in subjects with shortened dental arches. Journal of Oral Rehabilitation, 41 (2), 87-92.

Misch, C. E. (2002). The effect of bruxism on treatment planning for dental implants. Dentistry Today, 21 (9), 76-81.

Naert, I., Quirynen, M., van Steenberghe, D., \& Darius, P. (1992). A study of 589 consecutive implants supporting complete fixed prostheses. Part II: Prosthetic aspects. The Journal of Prosthetic Dentistry, 68 (6), 949-956.

Nishigawa, K., Bando, E., \& Nakano, M. (2001). Quantitative study of bite force during sleep associated bruxism. Journal of Oral Rehabilitation, 28 (5), 485491.

Pellizzer, E. P., de Mello, C. C., Junior, J. F. S., de Souza Batista, V. E., de Faria Almeida, D. A., \& Verri, F. R. (2015). Analysis of the biomechanical behavior of short implants: The photo-elasticity method. Materials Science and Engineering: C, 55, 187-192.

Pellizzer, E. P., Junior, J. F. S., Villa, L. M. R., de Souza Batista, V. E., de Mello, C. C., de Faria Almeida, D. A., \& Honório, H. M. (2014). Photoelastic stress analysis of splinted and unitary implant-supported prostheses. Applied Physics B, 117 (1), 235-244.

Pesqueira, A. A., Goiato, M. C., Monteiro, D. R., Santos, D. M. D., Haddad, M. F., \& Pellizzer, E. P. (2014). Use of stress analysis methods to evaluate the biomechanics of oral rehabilitation with implants. Journal of Oral Implantology, 40 (2), 217-228.

Radaelli, M. T. B., Idogava, H. T., Spazzin, A. O., Noritomi, P. Y., \& Boscato, N. (2018). Parafunctional loading and occlusal device on stress distribution around implants: A 3D finite element analysis. The Journal of Prosthetic Dentistry, 120 (4), 565-572.

Ramos Verri, F., Santiago Jr, F., Faria Almeida, D. A., de Souza Batista, V. E., Araujo Lemos, C. A., Cantieri Mello, C., \& Piza Pellizzer, E. (2017). Biomechanical three-dimensional finite element analysis of single implant-supported prostheses in the anterior maxilla, with different surgical techniques and implant types. International Journal of Oral \& Maxillofacial Implants, 32 (4), e191-e198.

Ribeiro, C. G., Maia, M. L. C., Scherrer, S. S., Cardoso, A. C., \& Wiskott, H. W. (2011). Resistance of three implant-abutment interfaces to fatigue testing. Journal of Applied Oral Science, 19 (4), 413-420.

Rubo, J. H., \& Capello Souza, E. A. (2010). Finite-element analysis of stress on dental implant prosthesis. Clinical Implant Dentistry and Related Research, 12 (2), 105-113.

Santiago Junior, J. F. S., Pellizzer, E. P., Verri, F. R., \& de Carvalho, P. S. P. (2013). Stress analysis in bone tissue around single implants with different diameters and veneering materials: a 3-D finite element study. Materials Science and Engineering: C, 33 (8), $4700-4714$.

Sevimay, M., Turhan, F., Kiliçarslan, M. A., \& Eskitascioglu, G. (2005). Three-dimensional finite element analysis of the effect of different bone quality on stress distribution in an implant-supported crown. The Journal of Prosthetic Dentistry, 93 (3), 227-234.

Silva, L. S., Verri., F. R., Lemos C. A. A., Martins, C. M., de Souza Batista, V. E. (2021). Biomechanical effect of an occlusal device for patients with an implant-supported fixed dental prosthesis under parafunctional loading: A 3D finite element analysis. The Journal of prosthetic dentistry. Online ahead of print.

Solnit, G. S., \& Schneider, R. L. (1998). An alternative to splinting multiple implants: use of the ITI system. Journal of Prosthodontics, 7 (2), $114-119$.

Suganuma, T., Itoh, H., Ono, Y., \& Baba, K. (2013). Effect of stabilization splint on occlusal force distribution during voluntary submaximal tooth clenching: a preliminary sleep simulation study. Cranio, 31(2), 100-108.

Torcato, L. B., Pellizzer, E. P., Verri, F. R., Falcón-Antenucci, R. M., Batista, V. E. D. S., \& Lopes, L. F. D. T. P. (2014). Effect of the parafunctional occlusal loading and crown height on stress distribution. Brazilian Dental Journal, 25 (6), 554-560. 
Research, Society and Development, v. 10, n. 6, e33610615601 2021

(CC BY 4.0) | ISSN 2525-3409 | DOI: http://dx.doi.org/10.33448/rsd-v10i6.15601

Torcato, L. B., Pellizzer, E. P., Verri, F. R., Falcón-Antenucci, R. M., Júnior, J. F. S., \& de Faria Almeida, D. A. (2015). Influence of parafunctional loading and prosthetic connection on stress distribution: A 3D finite element analysis. The Journal of Prosthetic Dentistry, 114 (5), 644-651.

Vázquez Álvarez, R., Pérez Sayáns, M., Gayoso Diz, P., \& García García, A. (2015). Factors affecting peri-implant bone loss: a post-five-year retrospective study. Clinical Oral Implants Research, 26 (9), 1006-1014.

Verri, F. R., Cruz, R. S., de Souza Batista, V. E., Almeida, D. A. D. F., Verri, A. C. G., Lemos, C. A. D. A., \& Pellizzer, E. P. (2016). Can the modeling for simplification of a dental implant surface affect the accuracy of 3D finite element analysis? Computer Methods in Biomechanics and Biomedical Engineering, $19(15), 1665-1672$

Verri, F. R., de Souza Batista, V. E., Santiago Jr, J. F., de Faria Almeida, D. A., \& Pellizzer, E. P. (2014). Effect of crown-to-implant ratio on peri-implant stress: a finite element analysis. Materials Science and Engineering: C, 45, 234-240.

Verri, F. R., Cruz, R. S., Lemos, C. A., de Souza Batista, V. E., Almeida, D. A., Verri, A. C., Pellizzer, E. P. (2017). Influence of bicortical techniques in internal connection placed in premaxillary area by 3D finite element analysis. Comput Methods Biomech Biomed Engin, 20, 193-200.

Wang, T. M., Leu, L. J., Wang, J. S., \& Lin, L. D. (2002). Effects of prosthesis materials and prosthesis splinting on peri-implant bone stress around implants in poor-quality bone: a numeric analysis. International Journal of Oral \& Maxillofacial Implants, 17 (2), 231-237.

Weinberg, L. A. (1993). The biomechanics of force distribution in implant-supported prostheses. International Journal of Oral \& Maxillofacial Implants, 8 (1), 19-31.

Yamanishi, Y., Yamaguchi, S., Imazato, S., Nakano, T., \& Yatani, H. (2012). Influences of implant neck design and implant-abutment joint type on periimplant bone stress and abutment micromovement: Three-dimensional finite element analysis. Dental Materials, 28 (11), 1126-1133. 